\title{
Cembengan: Implementation of The Nebu Sauyun Concept In The Giling Tebu Tradition In Tasikmadu Karanganyar, Central Java
}

\author{
Sudarsini $^{1}$, Andrik Purwasito ${ }^{2}$, Suwardi Endraswara ${ }^{3}$, Titis Srimuda Pitana ${ }^{4}$ \\ Student of Doktoral Program of Universitas Sebelas Maret, Surakarta, Indonesia ${ }^{1}$, Faculty of Social \\ and Political Sciences Universitas Sebelas Maret, Surakarta, Indonesia ${ }^{2}$, Faculty of Language and Art \\ Universitas Negeri Yogyakarta, Yogyakarta, Indonesia ${ }^{3}$, Faculty of Engineering Universitas Sebelas \\ Maret, Surakarta, Indonesia ${ }^{4}$ \\ \{sudarsini@ student.uns.ac.id\}
}

\begin{abstract}
This study examined Cembengan as an implementation of the Nebu sauyun concept in the tradition of giling tebu (milling sugarcane) at the Tasikmadu Sugar Factory (PG), Karanganyar, Central Java. The concept of Nebu sauyun can be found in Cembengan. This concept is the result of the thought of Prince Sambernyawa (Mangkunegara I). His thought is based on the principle of harmony as his efforts to uphold the existence of Pura Mangkunegaran. On the other hand, Mangkunegara IV as the successor to power also applies the principle of harmony, one of which is through the economic development field in the context of realizing the people welfare. The problem found was how the principles of harmony can be implemented internally and externally through Cembengan. This problem was examined through literature study using a cultural studies approach. The data obtained were processed through historical analysis. The results of this study found that Cembengan is a form of assimilation of the grave pilgrimage culture between Chinese and Javanese. In its development, this tradition extends to the preservation of temanten tebu rituals and traditional arts.
\end{abstract}

Keywords: cembengan, Nebu sauyun, temanten tebu

\section{Introduction}

In the beginning, sugar on the island of Java started from the western region, namely Banten and Batavia in the XVII to XVIII centuries. The Chinese people made sugar from sugar cane in the two cities. The tool used in the process of making sugar is a cylindrical stone called molen [1]. Meanwhile, local residents on the island of Java at that time only consumed sugarcane juice very simply. They immediately enjoy it from the stem as a sweetener and without being processed. The technology of processing sugar cane into sugar was not yet known at that time, so they felt satisfied consuming sugar through traditional sugarcane juice. This made the processing of sugar then handed over to the Chinese [2]. It can be said that the role of the Chinese in making sugar at that time was very meaningful, especially for the sustainability of production and fulfillment of sugar consumption in Indonesia.

The existence of a sugar factory in central Java was inseparable from the role of Mangkunegara IV, who at that time led the Mangkunegaran Praja. He founded PG Colomadu 
on December 8, 1861. This sugar factory is located close to Kartasura or the western part of Karanganyar Regency, Central Java. The establishment of the factory was the result of good relations with other parties, namely the representative Governor of the Dutch government and his good friend Be Bin Coan, a Chinese major from Semarang. The factory was managed well in its journey based on historical information. The second sugar factory, namely PG Tasikmadu, was then built as the second sugar factory on June 11, 1871. The factory is located in the same district, precisely in the east towards Tawangmangu.

Construction and management until 1874 were led by R. Kamp, someone who has experience in managing a sugar factory in Colomadu. The existence of PG Tasikmadu is an ideal factory because the driving force of the factory is water, while for milling it uses steam power which functions as backup power [3]. Based on the background that has been described, the purpose of this study is to answer internal and external problems of Mangkunegaran, whose results are then implemented through the cembengan tradition.

\section{Research Methods}

This research was a qualitative descriptive study through a historical approach. This research is called a research library based on the main data types used. The main data was obtained from historical records of the establishment of the sugar factory which was built by Mangkunegara IV in the mid-19th century. Meanwhile, secondary data was obtained from mass media articles related to the object of research. Historical analysis was used as a data processing method.

This analysis has the dominant characteristic of studying historical elements that are vigorous enough and worthy of consideration. Historical analysis shows the implications of the birth of Javanese local cultural values, namely the concept of Nebu sauyun which implies manunggal or harmony [4].

\section{Results and Discussion}

\subsection{The Concept of Nebu sauyun - The Ideals of Creating Harmony by Mangkunegara I}

The motto Nebu sauyun was very well known among the relatives of Mangkunegaran and became a link for various interests, strengths, and abilities in defending the pride of the Javanese people, upholding justice and truth to oppose the influence of the Dutch VOC [5]. In the document of the Surakarta "Suryasumirat" Mangkunegaran Relatives Association (Sukintaka, 1993), it is explained that Nebu sauyun is one of Mangkunegara I's life philosophie, manunggal ingkang angel separating saha murakabi. That statement literally means being one or in harmony so that they are not separated and through harmony will bring many benefits.

Mangkunegara I. This was motivated by the emergence of divisions within the palace which resulted in a power struggle between the princes. This unfavorable condition was then used externally by foreign parties, namely the Dutch to divide the Kraton. Initially, the relationship between the palace and the Netherlands was limited to cooperation in the trade sector. In the end, this involvement made the Dutch as the party who had the power to determine and decide important events within the palace so that the princes who were pro- 
Dutch submitted to their policies. On the other hand, for those who opposed the decision made by the Dutch, they rebelled. Mangkunegara I was one of the actors in the rebellion and led to prolonged warfare [6].

War is not profitable and does not solve problems, it tends to damage the joints of life. This made Mangkunegara I determined to end it marked by the Salatiga agreement. Thus, Mataram has been divided into three regions, namely Kasunanan and Mangkunegaran in Surakarta, and Kasultanan in Yogyakarta. Although Mangkunegara I's aspirations to unify Mataram did not materialize, his determination to build the Mangkunegaran dynasty continued. His determination was based on the pledge that the Mangkunegaran Praja could be used for the future life of their children and grandchildren. If his descendants do not pay attention and even cause damage to the descendants of Mangkunegaran officials, then the bless will not be given [3].

There is a very strong common thread in the philosophical teachings of Mangkunegara I with one another. The common thread is a framework in building a spirit of life struggle to preserve the descendants and the existence of Mangkunegaran. During the reign of Mangkunegara IV, the philosophical thoughts of his predecessors were reduced to philosophical thoughts of wirya, arta and winasis. That is, someone in his life should have social status, wealth, and intelligence [7].

In other words, Mangkunegara IV, armed with broad insights, will have skills in managing governance, one of which is in managing the Mangkunegaran economy. Through its success in managing the economy, it will have an impact on increasing income and in the end it will have an impact on the welfare of the Mangkunegaran interns and the common people as their supporters. If welfare can be guaranteed properly, then they can live side by side in harmony.

\subsection{Implementation of Nebu sauyun through Economic Development}

\section{Internally towards the Mangkunegaran Descendants}

The governance of the Mangkunegara I to Mangkuegara III period after the establishment of the Mangkunegaran Praja was structurally still traditionally centralized. Meanwhile, in the Mangkunegara IV era, a restructuring of the bureaucracy that blended Eastern and Western thoughts was carried out. There are efforts to improve governance by building the economy so that Mangkunegaran become stronger. Some of the business fields he has built are coffee cultivation, sugar cane plantations as well as sugar companies, tea, tobacco, quinine, and so on. The success of this development implies that Mangkunegaran is a prosperous and prosperous kaprajan (small country)[3].

Mangkunegaran as a kaprajan or 'small country' originated from the division of the Mataram kingdom. In modern governance, kings are no longer seen as representatives of God but they rule because of the contribution of the people. The people in this case were the fighters who supported the king against the Dutch colonialists and the rulers of Mataram who were considered despots. They struggle based on three principles of political culture, namely mulat sarira hangrasa wani, rumangsa melu handarbeni, melu hangrungkebi. The meaning contained in mulat sarira hangrasa wani is to understand oneself by doing self-introspection in order to overcome all obstacles.

Rumangsa melu handarbeni means that the Mangkunegaran praja belongs to the king and his people as a place to obtain a source of life. Melu hangrungkebi means that in the end the king and the people will jointly be obliged to defend it. These three principles then impressed 
Mangkunegaran so that the government bureaucracy was modernized and indirectly changed the existing etiquette [8].

\section{Externally Towards the Mangkunegaran supporters}

The relationship that existed between Mangkunegaran and his supporters was first started by Mangkunegaran I (Raden Mas Said / Pangeran Sambernyawa) long before the founding of Kaprajan. More precisely, since the time of his struggle against the invaders. This incident began during the Chinese war, namely the years 1740-1743, where there was an alliance between the Chinese and the Javanese against the Dutch VOC. This biggest war in Java had the widest area coverage, starting from the Gandaria area on the outskirts of Batavia and extending to almost the entire northern coast of Java, inland Java, to Pasuruan or Java in the eastern tip of Java [9].

Pigeaud [10] in the recapitulation written in his book Java in The 14th Century discusses the important position of the Chinese merchant community in Java since the 14th century. The trade relations between the Javanese Chinese and the Malay Chinese in the archipelago and the Chinese traders in South China and Vietnam appeared to have remained unstoppable for a long time. On the other hand, the destruction of the trading port cities on the north coast of Java and the cessation of Javanese Chinese trade was due to the development of Javanese internal politics, namely the emergence of the power of the inland kingdoms of Pajang and Mataram. However, with the very strong Dutch VOC power in Batavia in the early 17th century, this supported trade in several ways. At that time, the Javanese Chinese had adapted and had become a very strong part of the Javanese environment.

In the late 18th and early 19th centuries, the relations between the Javanese upper class and the Chinese community in the past were still maintained. The princes recognized the value of the Chinese people as businessmen, regular taxpayers, and most importantly that the Chinese could lend money. In Surakarta, both the Sunan and the Mangkunegaran Household Heads had contracts with both the Chinese and the Dutch Resident. The contract referred to here is a contract to pay a certain amount of rice each year. It aims to overcome the difficulties experienced by the palace [11].

The social interactions that took place between the Javanese and Chinese from the 14th to the 16th centuries experienced ups and downs. However, harmonization and tolerance always run well, even giving birth to culture and plurality which form harmony in religion and in social life. The harmonious relationship between the two ethnic groups can be seen especially when they stand together against the Dutch colonialists on Lasem land. Inter-ethnic cross-marriage consisting of Chinese, Javanese natives and santri, has occurred since the arrival of Chinese in Lasem [12].

The arrival of Chinese traders led by laksama Chen Ho in Semarang in 1412 proved that this event influenced the fusion of Chinese and Javanese culture. The trade relationship that occurred at that time still continues today. Even the Chinese immigrants who came to Java decided to stay. They were welcomed by the local people. However, due to cultural differences, Chinese immigrants prefer to live in their own community known as Chinatown. In that community, Chinese immigrants show an ethos of hard work. They start working from eight in the morning to five in the evening.

With their hard work they have an impact on indigenous people who see that family welfare can be achieved through hard work in business. [13]. This is the basis which is in line with Mangkunegara IV's thoughts that in order to improve people's welfare, it must be based on a good work ethic. This is stated in the fifth principle of Pancasila as the basis for the Unitary State of Indonesia. The fact about hard work is the most basic thing for every human being in 
his lifetime. In living life and becoming a citizen of a nation, hard work is an absolute must. In relation to the work ethic of the Chinese people, Vasanty in his research argues that in mobilizing the potential of each ethnicity or group, it is necessary to look at their potential. Ethnic Chinese in Indonesia have trade skills.

This intelligence is based on the nature of tenacity which we need to take advantage of and exemplify in sectors of economic development [14]. The values that can be taken include that in responding to the success of a person or group of other people, we should explore the underlying things. Thus, there is no need for one another to suspect each other, which in the end only leads to slander, suspicion and enmity.

According to Said [15] it is explained that the conditions that occurred for the anarchic actions of the indigenous people against ethnic Chinese in 1998 cannot be blamed. They committed these acts of anarchy because of poverty and ignorance as well as social jealousy towards ethnic Chinese who can economically live in prosperity and even be wealthy. The discrepancies that occur are not without cause, but because of the special treatment of the indigenous people themselves which provide convenience in terms of the economy so that they can develop businesses from generation to generation and even build giant companies in the country.

\subsection{Cembengan is a form of acculturation of the grave pilgrimage culture of the Chinese and Javanese}

By the practice of acculturation, it is hoped that it can reduce the friction that always occurs in society. Acculturation is a social process that arises when a group of people who have a certain culture is faced with elements from a foreign culture, so that the elements of the foreign culture are gradually accepted and processed into their own culture without causing the loss of the cultural personality itself [16]. Cembengan is one of the Chinese culture holidays in Indonesia. This holiday is also known as the Cheng Beng holiday, which means clean light. On that day, Chinese people made pilgrimages to their ancestors' graves with incense sticks, candles, prayer papers and some offerings. They went to the graves of the ancestors to clean it [14]. This ritual is similar to the Javanese tradition called sadranan or pamulen. That is, a ceremony to honor ancestors or relatives who have died, which is carried out once a year, to be precise in the month of Ruwah [5].

Over time, the Cheng Beng tradition was adopted and adapted in the first grinding ceremony for PG Colomadu and continued at PG Tasikmadu where the tradition was later called Cembengan. There is a story as told through the following sources in the implementation of the Cemvengan tradition. The prince is the ruler of Pura Mangkunegaran, namely Mangkunegara IV has a love story with Nyi Pulungsih, a girl from the Kapitan Chinese family of Semarang named Bhe Biauw Tjwan. Their story ended happily and was immortalized in the tradition of Cembengan in sugar factories in Central and East Java [17].

In Bauwarna Adat Javanese Procedure, Cembengan is interpreted as the first milling ceremony for a sugar factory in Java which is held in a big party during the sugarcane harvest season before the milling period begins. Therefore, cembengan is also often called the hustle and bustle of milled wiwit, which is the start of the period for grinding sugarcane into sugar. For sugarcane farmers and sugar factories, Cembengan is an expression of happiness and luck and hope for a smooth harvest and full of quality sugarcane juice.

To express gratitude, the ceremony is held or ceremony for the bride and groom of sugar cane which means that all that is expected is realized or achieved [5]. Pontjowolo [18], in his research discusses the history of the existence of sugar factories in Indonesia in general. The 
research specifically discusses the Cembengan tradition and its processions. The tradition of Cembengan is generally interpreted as a crowd in and around the factory in the context of the first milling selametan after the main harvest. This tradition is a process of bringing together two selected sugarcane stalks that are picked from different garden areas. In this case, sugarcane is personified like a bride and groom who are about to undergo a wedding process.

Therefore, several requirements that must be fulfilled are that the selected sugarcane stalks must be healthy, straight in shape, large in length, sweet in taste and sufficient in yield (sugar content). He further explained that traditionally picking sugarcane for harvest is still based on the calculation of a good day, namely Friday Pon. By doing so it is hoped that the harvest that will be carried out will bring safety, luck, and success. The values that can be taken in the procession are that humans should always remember the services of others in their lives, especially in this case their ancestors. A person in search of a welfare life should not forget that in the end everyone will return to the creator. Therefore, sufficient material provisions are needed so that they can do more good in their lives.

As a comparison, the Cembengan procession was also carried out in the Special Region of Yogyakarta. Shaleh [18] discusses the Cembengan procession in Madukismo PG belonging to the Yogyakarta palace which reflects the existence of a mystical synthesis. From there emerged the power struggle between orthodoxy and heterodoxy. This happened because the factory was a public company that naturally came from various religious groups. The traditions of Cembengan in PG Madukismo and PG Tasikmadu basically have the same thing, namely an activity that essentially asks for safety and blessings where in both processions there is a traditional ceremony of temanten tebu. As for the difference, in Madukismo PG there is a wayang golek (puppet show) while at PG Tasikmadu a performance of the typical Mangkunegaran Gambyong Pareanom dance and leatherpuppet performance tittled Sri Mulih [19].

\subsection{Cembengan, cultural preservation and economic development}

\section{Cembengan in the past}

The sugar business opportunity which was initiated by Mangkunegara IV by building the Colomadu sugar factory in 1861 was the beginning of the modernization and prosperity of the Javanese aristocrats [20]. Metz wrote that the goal of village community development, which in this case is included in the Mangkunegaran area, is to strengthen the morale of the people. People or village communities who have forward thinking are seen as the basis of defense for the old moral preservation. This was done during the reign of Mangkunegara VII with the aim of avoiding negative influences from the outside world that could endanger its people [8].

After independence, Mangkunegaran's power was automatically under the government of the Republic of Indonesia. Even though they have no sovereignty, the moral values of Mangkunegaran's ancestors are still carried out in the formation of the Republic of Indonesia. Without harmony to build unity through the spirit of mutual cooperation, surely NKRI cannot be realized.

\section{Cembengan in the present}

Cembengan in the present still refers to the days before Indonesia's independence by experiencing a few adjustments with the development of the era. Based on the online archive of the Karanganyar Regency Communication and Information Service for the last five years to 2019 , the order of the implementation of the Cembengan ritual is broadly the same, namely 
the procession begins with a grave pilgrimage, selametan, and a people's party event [21]. Even though PG Tasikmadu is almost a century and a half in 2019, the hardware inside is still very solid. Sugarcane ready to be milled at PG Tasikmadu comes from Karanganyar $(1,200$ hectares), Sukoharjo (800 hectares), Boyolali (450 hectares), Wonogiri (500 hectares), and Sragen (200 hectares). Sugarcane mill at PG Tasikmadu is targeted to produce 14,142 tons of sugar [22].

The people's party event in 2020 has been eliminated considering that the Indonesian nation and even the world is being hit by COVID-19 (Corona Virus Desease which began to hit since the end of 2019). It must be done in accordance with health protocols that prohibit the holding of an event that could crowd crowds. Therefore, starting from collecting the bridal sugar cane from the garden to the 'sugar cane wedding reception', it is only done by the internal company. The performance of wayang kulit, Reog, parade, and the night market that usually accompanies Cembengan is also canceled [23]. This is in line with the concept of Nebu sauyun, that in order to maintain togetherness, one of which is in terms of health, the policies of the local government must be implemented.

\section{Conclusion}

The results obtained in this study further strengthen that the Nebu sauyun tradition is still used as a guide, which literally means being one or harmonious so that they are not separated and with harmony will bring many benefits. Mangkunegara IV was the first Javanese and the first king to own a sugar factory that lived in the middle of the XIX century. He is a phenomenon, namely as a respected ruler and at the same time a poet with various actions that have brought Mangkunegaran reached its peak.

The sugar industry still has an inherent tradition and is still alive today. Mangkunegaran seemed to have modernized the government bureaucracy and indirectly changed the existing etiquette. The things he did at that time, for example, were related to the fulfillment of spiritual, physical, spiritual, biological elements, social economic development, cultural acculturation and the emergence of new terms according to the culture of each region so as to indirectly contribute to educating the people.

\section{References}

[1] L. H. Inagurasi, "Batu Silindris dan Budidaya Tebu di Banten, Batavia, dan Sekitarnya Pada Abad Ke 17-18 Cylindrik," J. Naditira Widya, vol. 9, no. 1, pp. 27-38, 2015.

[2] T. S. Raffles, The History Of Java. Terjemahan. Yogyakarta: Narasi, 2008.

[3] W. E. S. Siswokartono, Sri Mangkunegara IV sebagai Penguasa dan Pujangga. Semarang: Aneka Ilmu, 2006.

[4] N. K. Ratna, Metodologi Penelitian Kajian Budaya dan Ilmu-Ilmu Sosial Humaniora Pada Umumnya. Yogyakarta: Pustaka Pelajar, 2016.

[5] H. Bratasiswara, Bauwarna Adat Tata Cara Jawa. Jakarta: Yayasan Suryasumirat, 2000.

[6] M. C. Ricklefs, Sejarah Indoensia Modern 1200-2004. Jakarta: Ikrar Mandiriabdi, 2007.

[7] M. I. Birsyada and H. Joebagio, "Pemikiran Kewirausahaan Keluarga Mangkunegaran," Paramita Hist. Stud. J., vol. 26, no. 2, pp. 174-185, 2016.

[8] Wasino, "Modernisasi Budaya Politik Mangkunegaran,” Sej. dan Budaya, vol. 9, no. 2, pp. 257-263, 2015.

[9] Daradjati, Geger Pacinan 1740-1743. Jakarta: Penerbit Buku Kompas, 2017. 
[10] H. J. de Graaf dkk., Cina Muslim di Jawa Abad XV dan XVI: Antara Historisitas dan Mitos. Yogyakarta: Tiara Wacana, 2004.

[11] P. Carey, Orang Jawa dan Masyarakat Cina (1755-1825). Jakarta: Pustaka Azet, 1986.

[12] A. Atabik, "Percampuran Budaya Jawa dan Cina: Harmoni dan Toleransi Beragama Masyarakat Lasem," Sabda, vol. 11, pp. 1-11, 2016.

[13] Soegihartono, "Pengaruh Akulturasi Tionghoa \& Jawa Dalam Perkembangan Bisnis di Semarang," Respons, vol. 20, no. 02, pp. 187-211, 2015.

[14] P. Vasanty, "Kebudayaan Orang Tionghoa di Indonesia," in Manusia dan Kebudayaan di Indoensia, Koentjaraningrat, Ed. Jakarta: Djambatan, 2004, pp. 353-373.

[15] I. Said, "Hubungan Etnis Cina Dengan Pribumi," J. Mimb. Kesejaht. Sos., vol. 2, pp. 1-10, 2019.

[16] Koentjaraningrat, Pengantar Ilmu Antropologi. Jakarta: Rineka Cipta, 2015.

[17] I. Santosa, "Kisah Cinta Pangeran Jawa dan Gadis Tionghoa," kompas.id, Jakarta, Feb-2019.

[18] A. Q. Shaleh, "Religious Power Struggle and Cembengan Tradition in Madukismo Sugar Factory Yogyakarta,” Relig. J. Stud. Agama-Agama dan Lintas Budaya, vol. 4, no. 2, pp. 73-80, 2020.

[19] H. D. Pontjowolo, "Tradisi Selamatan Giling (Cembengan) PTP XV-XVI (PERSERO) P.G.Colomadu dan Tasikmadu Tahun 1992," Sukoharjo, 1992.

[20] I. Santosa and E. Hasby, "Dari Batu Penggiling Hingga Mesin Uap Tjolomadoe," kompas.id, Jakarta, Oct-2019.

[21] Diskominfo, "Tebu Manten Awali Musim Giling," https://www.karanganyarkab.go.id/20140509/tebu-manten-awali-musim-giling/, Karanganyar, May-2014.

[22] P. Suseno, "Bertahan 1,5 Abad, Begini Ritual Jelang Giling Tebu Di PG Tasikmadu Karanganyar," Solopos.com, Surakarta, May-2019.

[23] A. Alim, "Giling Tebu di PG Tasikmadu Tanpa Resepsi Pengantin,” Gatra.com, Jakarta, Apr-2020. 